\title{
Expression of AdipoR1 and AdipoR2 Receptors as Leptin-Breast Cancer Regulation Mechanisms
}

\author{
Martha Daniela Mociño-Rodríguez, ${ }^{1}$ Jonnathan Guadalupe Santillán-Benítez, ${ }^{1}$ \\ David Salomón Dozal-Domínguez, ${ }^{2}$ María Dolores Hernández-Navarro, ${ }^{1}$ \\ Miriam Veronica Flores-Merino, ${ }^{3}$ Antonio Sandoval-Cabrera, ${ }^{2}$ and \\ Francisco Javier García Vázquez ${ }^{4}$ \\ ${ }^{1}$ Faculty of Chemistry, Autonomous University of the State of Mexico (UAEMex), Toluca, MEX, Mexico \\ ${ }^{2}$ Specialized Hemato-Oncological Laboratory of the Children's Hospital, IMIEM, Toluca, MEX, Mexico \\ ${ }^{3}$ Molecular Biology Laboratory, Medical Research Center (CICMED), Toluca, MEX, Mexico \\ ${ }^{4}$ Laboratory of Immunohistochemistry, National Pediatrics Institute, Coyoacán, MEX, Mexico \\ Correspondence should be addressed to Jonnathan Guadalupe Santillán-Benítez; jonnathangsb@yahoo.com.mx
}

Received 24 May 2017; Accepted 20 July 2017; Published 5 September 2017

Academic Editor: Stefano M. M. Basso

Copyright (c) 2017 Martha Daniela Mociño-Rodríguez et al. This is an open access article distributed under the Creative Commons Attribution License, which permits unrestricted use, distribution, and reproduction in any medium, provided the original work is properly cited.

\begin{abstract}
The development of breast cancer is influenced by the adipose tissue through the proteins leptin and adiponectin. However, there is little research concerning AdipoR1 and AdipoR2 receptors and the influence of leptin over them. The objective of this work was to analyze the expression of AdipoR1 and AdipoR2, modulated by differential concentrations of leptin in an obesity model (10 ng/mL, $100 \mathrm{ng} / \mathrm{mL}$, and $1000 \mathrm{ng} / \mathrm{mL}$ ) associated with breast cancer in MCF-7 and HCC1937 cell lines. Each cell line was characterized through immunohistochemistry, and the expression of AdipoR1 and AdipoR2 was analyzed by PCR in real time using TaqMan ${ }^{\circledR}$ probes. Leptin induced an increase in cell population of MCF-7 $(23.8 \%, 10 \mathrm{ng} / \mathrm{mL}, 48 \mathrm{~h})$ and HCC1937 (17.24\%, $1000 \mathrm{ng} / \mathrm{mL}, 72 \mathrm{~h})$. In MCF-7, the expression of AdipoR1 decreased $(3.81 \%, 1000 \mathrm{ng} / \mathrm{mL})$ and the expression of AdipoR2 increased by 13.74 times $(10 \mathrm{ng} / \mathrm{mL})$ with regard to the control. In HCC1937, the expression of AdipoR1 decreased by $86.28 \%$ $(10 \mathrm{ng} / \mathrm{mL})$, as well as the expression of AdipoR2 $(50.3 \%, 100 \mathrm{ng} / \mathrm{mL})$. In regard to the results obtained, it could be concluded that leptin has an effect over the expression of AdipoR1 and AdipoR2 mRNA.
\end{abstract}

\section{Introduction}

Over the last 20 years, the development of breast cancer has been associated to lifestyle changes, primarily to obesity [1]. Obesity is considered an excess in the accumulation of adipose tissue produced when caloric intake exceeds energy consumption [2]. Besides storing excess calories in the form of lipids, the adipose tissue participates through diverse forms in the development of cancer due to the fact that it also acts as an endocrine gland, liberating the adipocytokines leptin and adiponectin and proinflammatory molecules [3].

Leptin is a protein produced from the OB gen or "gen of obesity" [4]. The expression of the gen is restricted to adipose tissue, and its levels are closely related to the storage of triglycerides and the mass of adipose tissue [5]. It is a pleiotropic adipocytokine which regulates the ingestion of foods, energy consumption, immunity, inflammation, hematopoiesis, cell differentiation, and proliferation $[6,7]$.

Adiponectin is a protein produced exclusively in white adipose tissue [8] and is considered as a protection hormone, carrying out an important role in the regulation of glucose through a potent sensitizing effect towards insulin, which affects the uptake of glucose in the muscle and participates in the homeostasis of lipids [9]. Its plasmatic concentration has an inversely proportional relationship towards obesity, body mass index, accumulation of visceral fat, and insulin resistance $[10,11]$. It carries out its function through two specific receptors, AdipoR1 and AdipoR2, which are receptors 
coupled to $G$ proteins with six transmembrane domains. AdipoR1 is predominantly expressed in striated muscle, while AdipoR2 is mainly expressed in the liver [12]. The bonding of adiponectin to its receptors increases the activity of the AMP-dependent protein kinase (AMPK) and the peroxisome proliferator-activated alpha receptor (PPAR- $\alpha$ ), favoring the oxidation of fatty acids and the entrance of glucose into tissues [13]. The activated AMPK system plays a vital role in the regulation of the energetic metabolism and cell quiescence $[14,15]$.

The pathologies, which modify the biology of adipose tissue, such as obesity, and produce an alteration in the secretion of these adipocytokines, increasing the liberation of leptin, VEGF, IL-6, and TNF- $\alpha$ and decreasing the secretion of adiponectin could be linked to different carcinogenic mechanisms including cell differentiation, apoptosis, cell proliferation, angiogenesis, and alteration of steroidal sex hormone levels [9].

This variation in the secretion of adipocytokines by the adipose deposits may explain the relationship between obesity and the development of breast cancer, since obese subjects present a decrease in the levels of circulating adiponectin and increase in the plasmatic concentration of leptin $[5,16]$.

The aforementioned has been observed in diverse in vitro experiments, in which the promoting activity of proliferation in breast cancer cell lines by leptin is mediated through different signal pathways; on one hand, it acts by inducing the P13K/Akt survival pathway, activating the phosphorylation of Akt, stimulating protein expression of PKC-alpha, activating the MAPK pathway, and stimulating ERK1 and ERK2 [17-20]. It activates the STAT3 pathway and induces upregulation of c-myc at an mRNA level, as well as at a protein level. Likewise, it upregulates genes of the cell cycle (cyclin D1) and reduces the expression of p53 and the production of Bax [21-23]. Some studies suggest that leptin may promote angiogenesis in breast cancer through the signaling of VEGF [24]. In this manner, it can be deduced that the procarcinogenic effect of leptin derives from the activation of signaling pathways implicated in the cell proliferation process and a downregulation of the apoptotic response $[25,26]$.

Likewise, the antiproliferative action of breast cancer cells by adiponectin is mediated by an inactivation of protein 1 and 3 expression in MAPK p44/42, a stimulation of AMPK activity and a decrease in phosphorylation of Akt, associated with an increased expression of LKB1, reducing the activity of mTOR and leading to a decrease in the production of reactive oxygen species [19, 27-29]. Studies suggest that adiponectin modulates the cell cycle of breast cancer cells, decreasing the expression of cyclin D1 $[30,31]$. In diverse studies, it has been detected that adiponectin induces cell apoptosis when a stimulus is given to cell lines with an incubation period longer than $48 \mathrm{~h}[32,33]$. Also, an increase of PPAR in estrogen-positive cell lines, the downregulation of $\mathrm{Bcl} 2$, and the activation of $\mathrm{p} 53$ and Bax have been detected $[34,35]$. Finally, it is suggested that an interaction of adiponectin and estrogen pathways exists, since it is capable of reducing aromatase and the expression of the receptor [36].
For the identification of the procarcinogenic mechanisms of leptin, the breast cancer cell lines MCF-7, MDA-MB-231, and T47D have been characterized for the protein and its receptor [Ob-R), studying its effect over cell growth in the MCF-7, SK-BR-3, T47D, and ZR-75-1 cell lines. An increase in cell proliferation when the cells receive a single stimulus of leptin and incubated between 24 and $96 \mathrm{~h}$ has been observed [21, 27, 28, 37, 38].

In order to better understand the potential involvement of leptin in the expression of adiponectin receptors, AdipoR1 and AdipoR2, in the cells of breast cancer, the main objective of this research was to demonstrate that AdipoR1 and AdipoR2 were expressed in MCF-7 and HCC1937 breast cancer cell lines, as well as to determine and analyze the expression of these receptors modulated by differential concentrations of leptin [27].

\section{Materials and Methods}

2.1. Cell Culture. For this study, cell lines MCF-7 and HCC1937 were employed and were obtained from the American Type Culture Collection (ATCC). They were cultivated at $37^{\circ} \mathrm{C}$ in an atmosphere of 5\% CO2 and $85 \%$ humidity, with culture medium (RPMI 1640 medium, Gibco $^{\circledR}$, Thermo Fisher Scientific ${ }^{\mathrm{TM}}$, Dulbecco's modified Eagle's medium, Caisson Labs, USA) supplemented with $10 \%$ fetal bovine serum (Gibco, Thermo Fisher Scientific, USA), inactivated by heat $\left(30 \mathrm{~min}\right.$ at $57^{\circ} \mathrm{C}$; water bath), with medium exchange every third day.

2.2. Immunohistochemistry. The expression of estrogens (RE), progesterone (RP), Her2, and Ki67 was determined through immunohistochemistry. Once a confluence of $70 \%$ of cells was reached, they were washed with PBS (phosphate-buffered saline, Gibco, Thermo Fisher Scientific, USA) and were suspended with $0.05 \%$ trypsin (Gibco, Canada). The recuperated cells were centrifuged for $3 \mathrm{~min}$ at $1500 \mathrm{rpm}$, and the cell pellet was then used to prepare slides fixed with acetone. Posteriorly, the recuperation of epitopes was done, utilizing $0.1 \%$ sodium citrate (Dako, USA, $\mathrm{pH}$ 6.2), inactivating endogenous peroxidase with $0.9 \%$ hydrogen peroxide. The slides were washed with distilled water and were placed in PBS for 5 minutes [39]. The cells were then incubated during 45 minutes with the following antibodies: RE 1:35 (Dako, USA), RP 1:50 (Dako, USA), Her2 1:50 (Biocare, USA), and Ki67 1:100 (Biocare, USA).

Next, a two-step detection system was incorporated (Mach 1 Universal HRP-Polymer Detection, Biocare, USA) during 30 minutes each. The reaction was visualized with 3,3'-diaminobenzidine (Leica Biosystems, USA) and was stained with Hill's hematoxylin [39].

2.3. Proliferation Assay. The study of cell proliferation was carried out through the crystal-violet assay. For this purpose, two groups of 5000 MCF-7 and HCC1937 cells were inoculated in 96-well culture plates and were left to grow during $24 \mathrm{~h}$ (group 1) and $48 \mathrm{~h}$ (group 2). Afterwards, each group was washed every $24 \mathrm{~h}$, during $96 \mathrm{~h}$, with PBS and fresh 
culture medium (supplemented with 5\% SFB) with leptin stimuli, which was added (Recom Hu Leptin Active, Sino Biological, Thermo Fisher Scientific, USA) in concentrations of $0 \mathrm{ng} / \mathrm{mL}$ (negative control), $10 \mathrm{ng} / \mathrm{mL}, 100 \mathrm{ng} / \mathrm{mL}$, and $1000 \mathrm{ng} / \mathrm{mL}$ [27]. The decrease of SFB was done to reduce the growth factors that could interfere with the action of leptin [40].

Cell proliferation in each cell line was determined in triplicate for every concentration evaluated. After $24 \mathrm{~h}$ of stimulation, the cells were fixed with $1.1 \%$ glutaraldehyde (Merck, Germany) during 15 minutes and then PBS was added until the $96 \mathrm{~h}$ of stimulation with leptin was concluded for each group. At the end of stimulation, the fixed cells were stained with crystal-violet for 15 minutes, the plate was washed with water, and $10 \%$ acetic acid was placed in each well. Immediately after, the plate was read at an excitation wavelength of $490 \mathrm{~nm}$ and an emission wavelength of $630 \mathrm{~nm}$ in a microplate reader (Stat Fax 2100 Microplate Reader, Awareness Technology Inc.)

2.4. Analysis of Microassays. The regulation of gene expression of adiponectin receptors AdipoR1 and AdipoR2 was evaluated by means of the addition of leptin to the cell lines following the methodology proposed by Jardé et al., [27], with slight modifications. 2000 MCF-7 and HCC1937 cells were cultured in 24-well culture plates, allowing them to grow during $48 \mathrm{~h}$.

After $24 \mathrm{~h}, 48 \mathrm{~h}, 72 \mathrm{~h}$, and $96 \mathrm{~h}$, the cells were washed with PBS and fresh culture medium (supplemented with 5\% SFB) with leptin stimuli $(0 \mathrm{ng} / \mathrm{mL}, 10 \mathrm{ng} / \mathrm{mL}, 100 \mathrm{ng} / \mathrm{mL}$, and $1000 \mathrm{ng} / \mathrm{mL}$ ) was added. At the end of the stimulation, the culture medium was removed and $400 \mu \mathrm{L}$ of TRIzol $^{\circledR}$ reagent was added to carry out the mRNA extraction, in accordance with the protocol of use (Ambion ${ }^{\mathrm{TM}}$ ).

Once the mRNA was obtained, the acquisition of the complementary DNA was carried out (cDNA) from $2 \mu \mathrm{g}$ of mRNA through the reverse transcriptase reaction, in accordance with the protocol of use (high-capacity RNA to cDNA kit, Applied Biosystems), obtaining $20 \mu \mathrm{L}$ of cDNA.

The cDNA of the controls of each cell line were used to determine, through endpoint PCR (HotStarTaq DNA Polymerase, QIAGEN, Germany), the presence of AdipoR1 mRNA (Fw: 5'-AATTCCTGAGCGCTTCTTTCCT-3', Rv: 5'-CATAGAAGTGGACAAAGGCTGC-3') and AdipoR2 mRNA (Fw: 5'-TGCAGCCATTATAGTCTCCCAG-3, Rv: 5'-GAATGATTCCACTCAGGCCTAG-3'), using the ACTB control gen (Fw: 5'-GCACCACACCTTCTACAAAG-3', Rv: 5'-GGTCTCAAACATGATCTGGTC-3').

Likewise, the cDNA obtained through the stimuli was used to determine the gene expression of AdipoR1 and AdipoR2 through real-time PCR (TaqMan Universal Mix II, with UNG), utilizing TaqMan probes (Gene Expression Assays, Applied Biosystems) for AdipoR1 (Hs 01114951_ml) and AdipoR2 (Hs 00226105_ml), using the ACTB gene as a control (Hs 99999903_ml), following the instructions of the LightCycler ${ }^{\circledR} 2.0$ thermocycler (Roche Diagnostics). The program utilized to carry out the PCR was $50^{\circ} \mathrm{C}$ for 2 minutes, $95^{\circ} \mathrm{C}$ for $10 \mathrm{~min}, 40$ cycles at $95^{\circ} \mathrm{C}$ for 15 seconds, and $60^{\circ} \mathrm{C}$ for $1 \mathrm{~min}$.
For the determination of relative levels of AdipoR1 and AdipoR2 gene expression, the Pfaffl method of relative quantification, based on the comparison of the threshold cycle of a constitutive gene (mRNA of ACTB) with the test gene of each sample in duplicate, was carried out. The change in the fold of AdipoR1 and AdipoR2 was normalized with regard to the reference genes expressed constitutively and was then compared with the nontreated controls as follows: $2^{-\Delta \Delta C T}$, where $\Delta \Delta \mathrm{CT}=\Delta \Delta \mathrm{CT}=\left(C_{\mathrm{T} \text {-target }}-C_{\mathrm{T}-\text { reference }}\right)_{\text {treated sample }}-$ $\left(C_{\mathrm{T}-\text { target }}-C_{\mathrm{T}-\text { reference }}\right)_{\text {calibrating sample }}$ "Calibrating sample" refers to the level of expression $(1 \times)$ of the target gene normalized for the constitutive gen. The calibrator was chosen from the control group of each cell line and was given a value of 1 for relative expression [41-43].

\section{Statistical Analysis}

Statistical analysis was performed using GraphPad Prism 6 software. To analyze the results of the growth curves of each cell line, a two-factor ANOVA was performed with a $p$ value $>0.05$, to establish the relationship between incubation time and leptin concentrations.

For the analysis of gene expression results of AdipoR1 and AdipoR2, we first tested a normality hypothesis using the Kolmogorov-Smirnov test. Subsequently, the Student's $t$-test was performed for the parametric variables and the Mann-Whitney $U$ test for the nonparametric variables with a $p$ value $>0.05$ for each one.

\section{Results}

4.1. Characterization by Immunohistochemistry. The selection of the cell lines employed in this experiment was done in accordance with the molecular classification of breast cancer, in other words, in accordance with the hormonal receptors that are found expressed by the cells.

Using the immunohistochemistry technique, each cell line was characterized according to the molecular classification "triple positive" (MCF-7) and "triple negative" (HCC1937), evaluating the presence of Ki67, estrogen (RE), progesterone (RP), and Her2 (Figure 1).

MCF-7, a cell line identified as "triple positive," had an expression positive for Ki67 at 78\% (78 cells out of 100), RE at $45 \%$ ( 45 cells out of 100 ), RP at $5 \%$ (5 cells out of 100 ), and Her2 at $14 \%$ (14 cells out of 100$)$.

In contrast to MCF-7, HCC1937 breast cancer cells presented an expression negative for RE, RP, and Her2. For Ki67, they presented an expression positive at 7\% (7 cells out of 100), as shown in Figure 1.

4.2. Expression of Leptin, Adiponectin, AdipoR1, and AdipoR2 in Breast Cancer Cell Lines. The mRNA of leptin and adiponectin was detected in MCF-7 breast cancer cells through endpoint PCR, observing a greater expression of leptin mRNA when compared to adiponectin mRNA, in accordance with the bands obtained in the electrophoretic gel, as shown in Figure 2. With regard to HCC1937, a triple-negative cell line with a mutation in BRCA1 [44], 

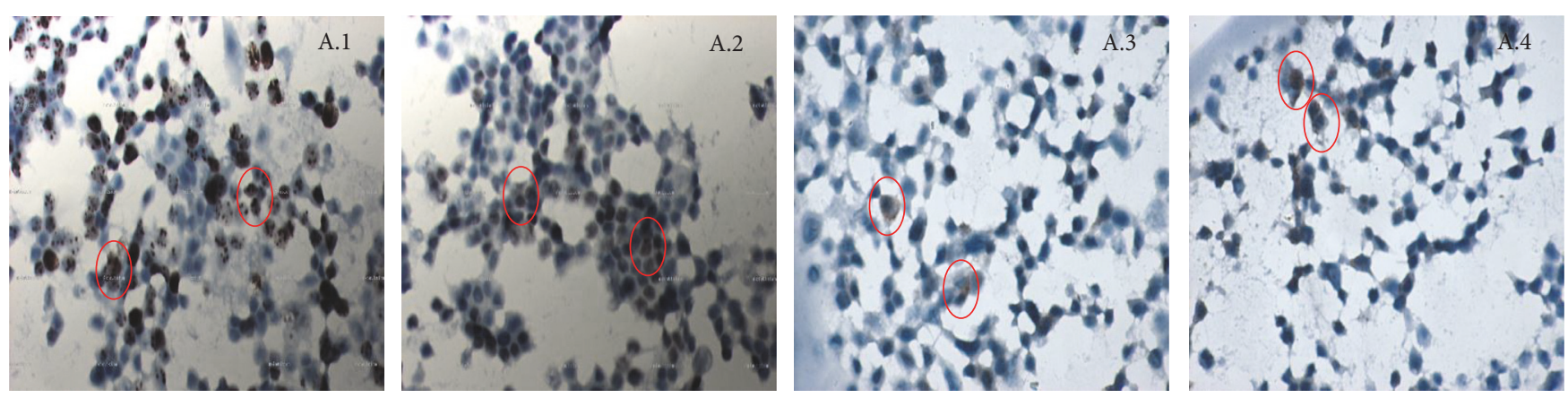

(a)
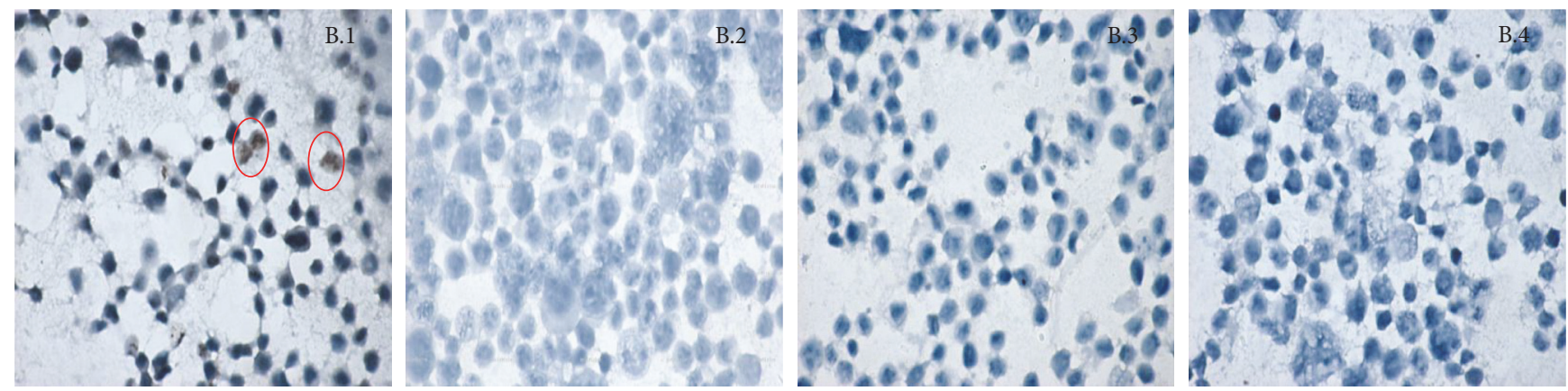

(b)

Figure 1: Characterization through immunohistochemistry of MCF-7 and HCC1937 cells. Detection through immunohistochemistry of the Ki67 protein, estrogen receptor (ER), progesterone receptor (PR), and Her2 in breast cancer cell lines. MCF-7 expression positive for Ki67 (A.1), ER (A.2), PR (A.3), and Her2 (A.4). HCC1937 cells exhibited an expression positive for Ki67 (B.1), while they showed an expression negative for ER (B.2), PR (B.3), and Her2 (B.4).

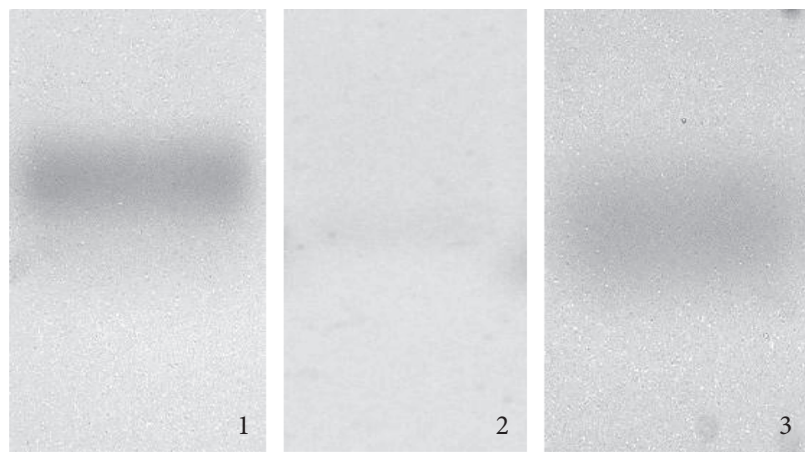

(a)

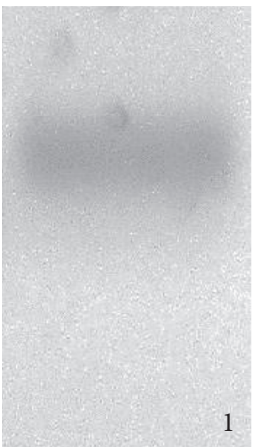

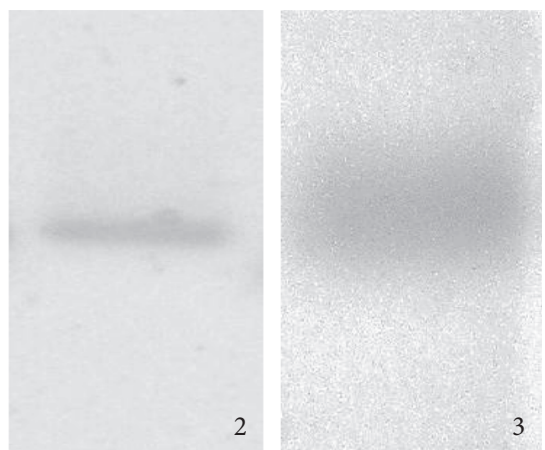

(b)

Figure 2: Detection of the expression of ABL control gene mRNA (1), adiponectin (2), and leptin (3) through endpoint PCR in MCF-7 (a) and HCC1937 (b) cells.

it was also possible to determine the expression of these genes (Figure 2).

As far as AdipoR1 and AdipoR2 mRNA is concerned, it was detected in MCF-7 and HCC1937 cells through endpoint PCR. In MCF-7, two adiponectin receptors, AdipoR1 and AdipoR2, were found to be expressed, just as Jardé et al. had reported [27]. As in the case of leptin and adiponectin, HCC1937 expresses these two receptors, a line that was not found to be reported "positive" in literature (Figure 3).

In both cell lines, the expression of AdipoR2 mRNA is greater with regard to BACT and AdipoR1 mRNA expression, in agreement with the bands obtained in the electrophoretic gel, as can be seen in Figure 3.

Once it was proven that the three cell lines studied express AdipoR1 and AdipoR2 mRNA, the quantitative determination of the expression of these receptors through real-time PCR, utilizing BACT as a control, went underway.

4.3. Effect of Leptin over Cell Proliferation of MCF-7 and HCC1937 Breast Cancer Cells. In the cells which were subjected to the leptin stimuli $24 \mathrm{~h}$ after culture (group 1), a negative effect was observed (antiproliferative) in cell 


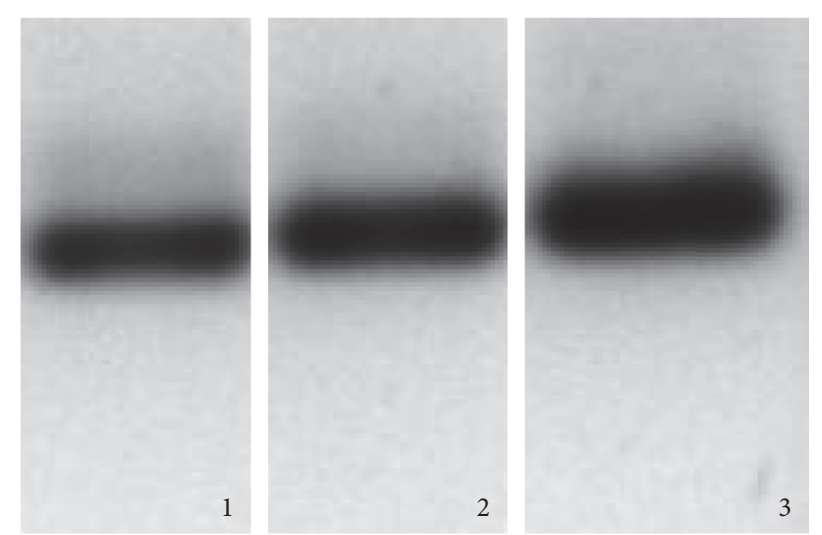

(a)

Figure 3: Detection of ACTB mRNA expression (1), AdipoR1 HCC1937 cells (b).

proliferation in relation to leptin concentrations. With regard to MCF-7 cells, the cell population decreased $64.71 \%$ $(1000 \mathrm{ng} / \mathrm{mL}, 96 \mathrm{~h})$, except at $1000 \mathrm{ng} / \mathrm{mL}$, where it increased $30.77 \%$ after $72 \mathrm{~h}$ of stimulation. The cell growth of HCC1937 decreased at all concentrations, up to $57.14 \%$ (1000 ng/mL, $24 \mathrm{~h}$ ) (Figure 4).

In relation to the cells that were subjected to the leptin stimuli $48 \mathrm{~h}$ after culture (Group 2), a positive effect was observed in cell proliferation with relation to leptin concentrations. With regard to MCF-7, the effect of this protein over cell proliferation was positive, increasing by $28.57 \%$ (10 ng/ $\mathrm{mL}, 48 \mathrm{~h}$ ); this effect was maintained until $72 \mathrm{~h}$, at a concentration of $1000 \mathrm{ng} / \mathrm{mL}$, where there was a $3.45 \%$ increase with regard to the control. It was observed that for the concentration that corresponds to normal weight $(10 \mathrm{ng} / \mathrm{mL})$, the positive effect of leptin was maintained until $48 \mathrm{~h}$ and decreased by $6.90 \%$ with the third stimuli $(72 \mathrm{~h})$ and posteriorly presented an increase in the cell population once again at $96 \mathrm{~h}$; not so for the concentration of $100 \mathrm{ng} / \mathrm{mL}$, where at $72 \mathrm{~h}$ of stimulation, the cell population decreased by $26.68 \%$. The cell growth of HCC1937 decreased by $23.46 \%$ (1000 ng/mL, $24 \mathrm{~h}$ ), except after $72 \mathrm{~h}$, at which all the concentrations presented an increase in the cell population, up to $17.24 \%$ $(1000 \mathrm{ng} / \mathrm{mL})$, maintaining themselves until $96 \mathrm{~h}$, where there was an increase of $0.49 \%$ at $10 \mathrm{ng} / \mathrm{mL}, 0.25 \%$ at $100 \mathrm{ng} / \mathrm{mL}$, and $10.31 \%$ at $1000 \mathrm{ng} / \mathrm{mL}$ with regard to the control, indicating that the higher the concentration of leptin, the higher the increase in cell population. It was observed that, despite the fact that the cell population was maintained above the control at all times and concentrations after $48 \mathrm{~h}$ of stimulation, there was a gradual decrease of cells, as can be seen in Figure 4.

4.4. Expression of AdipoR1 and AdipoR2 Mediated by Leptin in Breast Cancer Cell Lines. The mRNA of AdipoR1 and AdipoR2 was detected in MCF-7 and HCC1937 cell lines through real-time PCR. The expression of AdipoR1 and AdipoR2 in mRNA was determined in cells that were stimulated with leptin at differential concentrations $(0 \mathrm{ng} / \mathrm{mL}$, $10 \mathrm{ng} / \mathrm{mL}, 100 \mathrm{ng} / \mathrm{mL}$, and $1000 \mathrm{ng} / \mathrm{mL}$ ) in both cell lines.
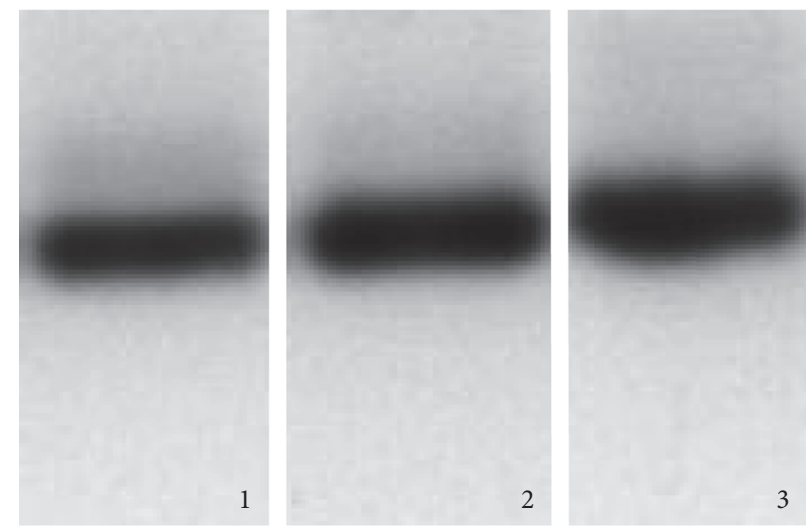

(b)

(2), and AdipoR2 (3) through endpoint PCR in MCF-7 (a) and

In MCF-7, the expression of AdipoR1 had a decrease of $3.81 \%(1000 \mathrm{ng} / \mathrm{mL})$ in the cells treated with leptin with regard to the control, except for $100 \mathrm{ng} / \mathrm{mL}$, where there was a $64.03 \%$ increase in the expression of the gene. However, the expression of AdipoR2 increased considerably in the cells treated with leptin (up to 13.74 times; $10 \mathrm{ng} / \mathrm{mL}$ ), with regard to the control (Figure 5).

Analyzing the normalized values of treated cells in the MCF-7 line, no statistically significant differences were found in the expression of AdipoR1 between the controls and the cells treated with differential concentrations of leptin: $10 \mathrm{ng} / \mathrm{mL}(p=0.0945), 100 \mathrm{ng} / \mathrm{mL}(p=0.760)$, and $1000 \mathrm{ng} /$ $\mathrm{mL}(p=0.7840)$. However, upon analyzing the normalized values of treated cells for the expression of AdipoR2, statistically significant differences were found between the controls and the cells treated with differential concentrations of leptin: $10 \mathrm{ng} / \mathrm{mL}(p=0.0022), 100 \mathrm{ng} / \mathrm{mL}(p=0.0022)$, and $1000 \mathrm{ng} / \mathrm{mL}(p=0.0022)$ (Table 1$)$.

In HCC1937, the expression of AdipoR1 decreased in cells treated with leptin with regard to the control, as much as $86.28 \%(10 \mathrm{ng} / \mathrm{mL})$, while the expression of AdipoR2 had a decrease in the cells treated with leptin with regard to the control, as much as $50.3 \%(100 \mathrm{ng} / \mathrm{mL})$, which can be seen in Figure 5.

Analyzing the normalized values of treated cells in the HCC1937 line, statistically significant differences were found with regard to the controls for the expression of AdipoR1 in the cells treated: $10 \mathrm{ng} / \mathrm{mL}(p=0.0043)$ and $1000 \mathrm{ng} / \mathrm{mL}$ $(p=0.0130)$. For the cells treated with $100 \mathrm{ng} / \mathrm{mL}$ of leptin, no statistically significant differences were found for the expression of AdipoR1. As for the expression of AdipoR2, upon analyzing the normalized values of treated cells, no statistically significant differences were found between the controls and the cells treated with differential concentrations of leptin: $10 \mathrm{ng} / \mathrm{mL}, 100 \mathrm{ng} / \mathrm{mL}$, and $1000 \mathrm{ng} / \mathrm{mL}$ (Table 1).

\section{Discussion}

It has been determined that obesity and excess weight are risk factors for the development of breast cancer in women 


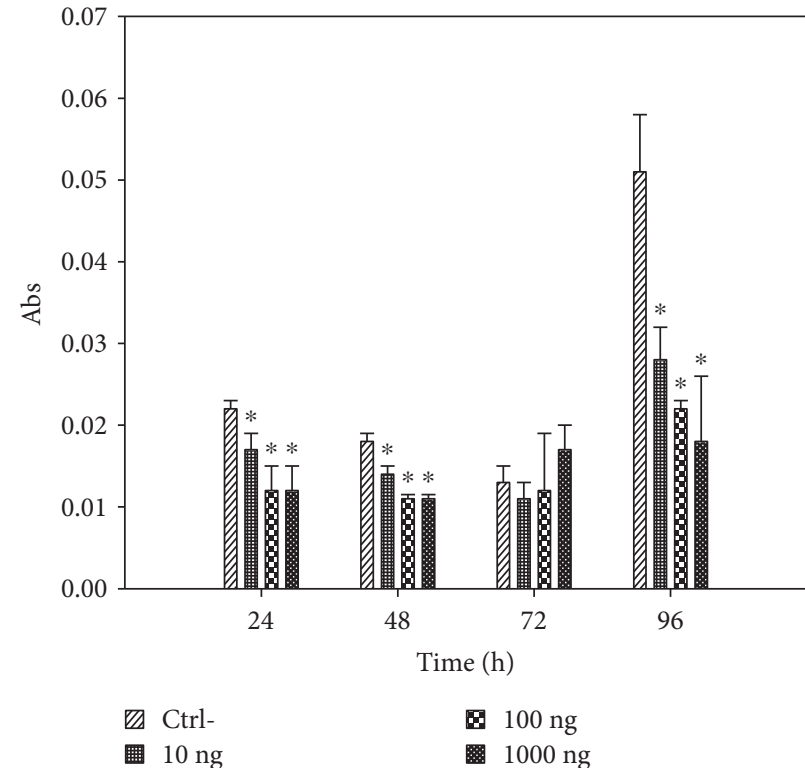

(a)

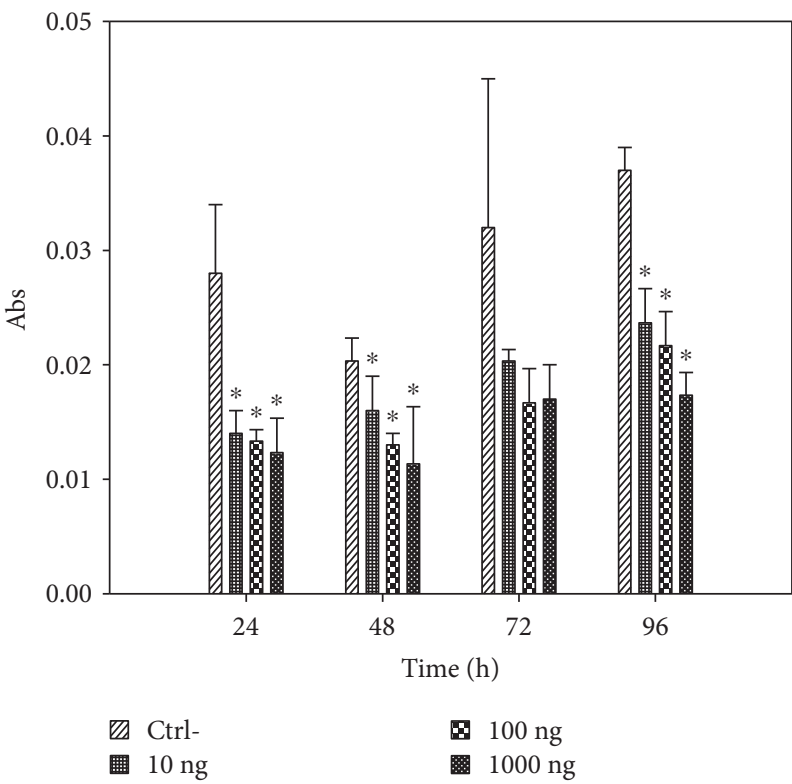

(c)

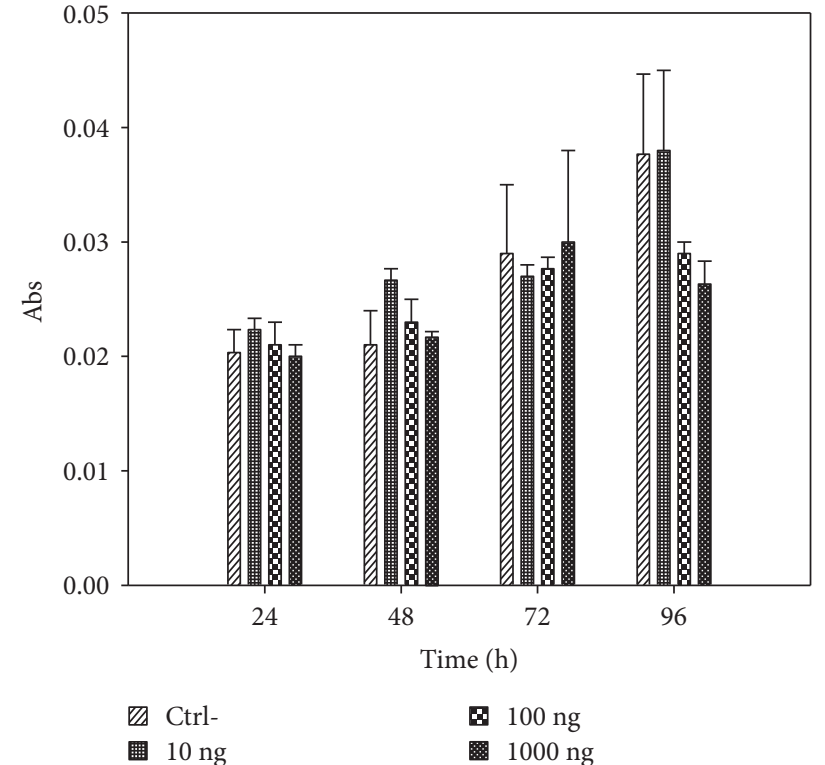

(b)

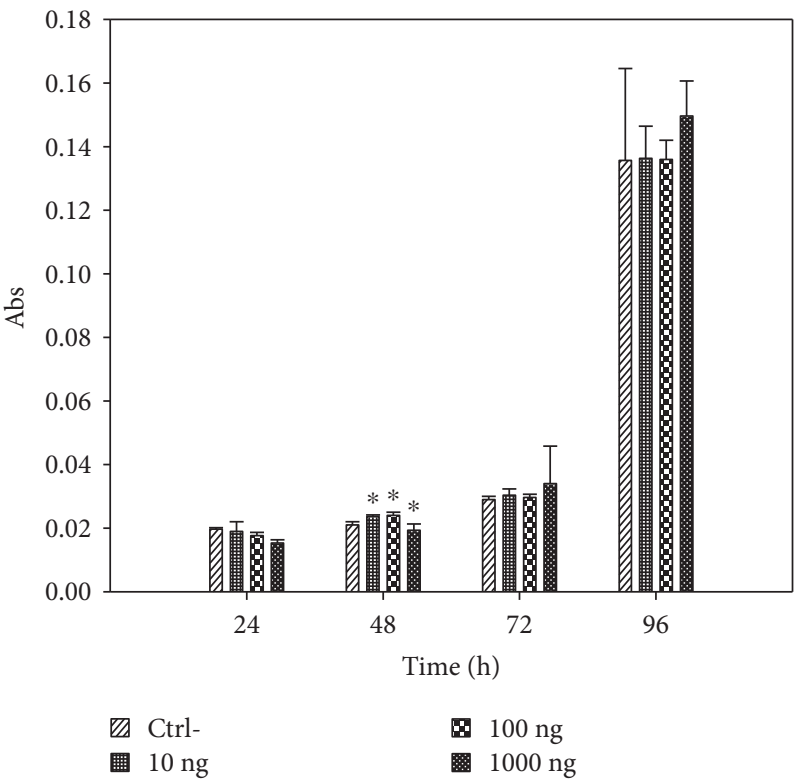

(d)

FIGURE 4: Cell viability with leptin stimulation. The data is expressed in mean $\pm \mathrm{SD}, n=3$. Effect of leptin in MCF-7 breast cancer cells (a) at application of the first stimuli $24 \mathrm{~h}$ after cell culture, (b) MCF-7 cells at application of first stimuli $48 \mathrm{~h}$ after cell culture, (c) HCC1937 cells at application of first stimuli $24 \mathrm{~h}$ after cell culture, and (d) HCC1937 cells at application of first stimuli 48 hours after cell culture. *Significant differences compared with the control (ANOVA test, $p<0.05$ ).

(occidental and Asian) $[45,46]$. The procarcinogenic effect of leptin and the anticarcinogenic effect of adiponectin is mainly due to two mechanisms: (1) modulation of signaling pathways implicated in the proliferation process and (2) subtle regulation of the apoptotic response [4].

The characterization of each cell line through the immunohistochemistry technique was carried out according to the molecular classification "triple negative" (MCF-7) and "triple negative" (HCC1937), which allowed for the observation that in MCF-7, the estrogen receptor presented an expression 9 times greater than the progesterone receptor and up to
3.21 times greater than Her2. HCC1937 presented a negative expression for RF, PR, and Her2, which corresponds to that reported in the literature [47], in addition to the 7\% Ki67 expression.

The effect of leptin over cell growth has been determined in MCF-7, MDA-MB231, SK-BR-3, T47D, and ZR-75-1 breast cancer cell lines, mediated by diverse signaling pathways when a single stimulus of the protein is applied and is incubated between 24 and $96 \mathrm{~h}[21,27,37,38,48,49]$. In this study, protein stimuli was applied every $24 \mathrm{~h}$ in order to emulate the constant secretion of the said protein by adipose 


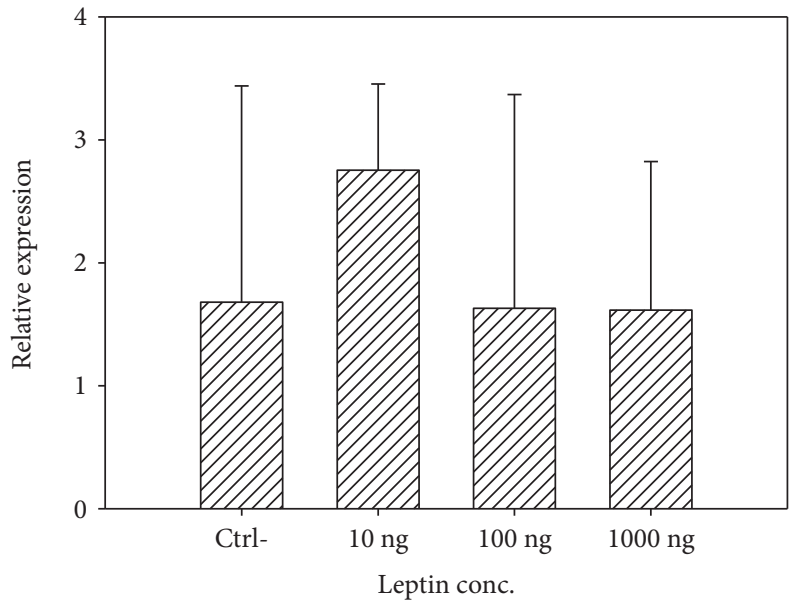

(a)

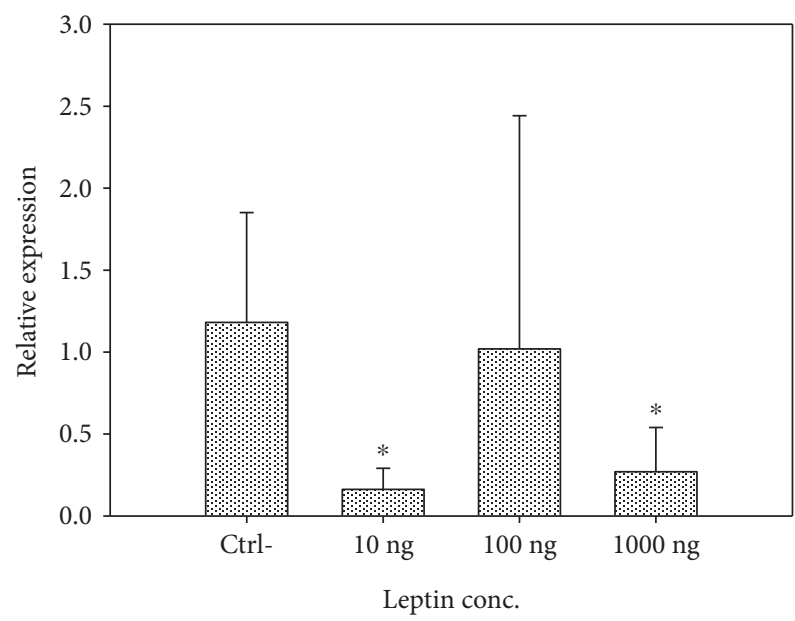

(c)

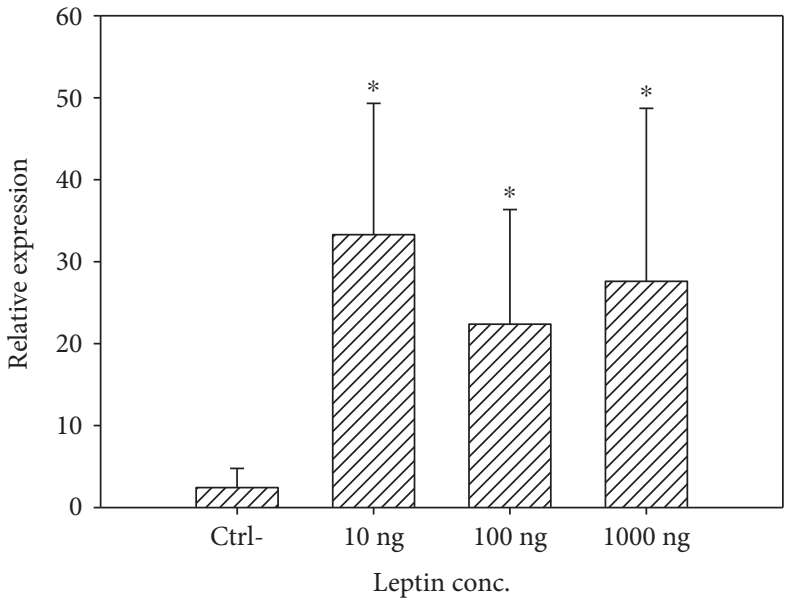

(b)

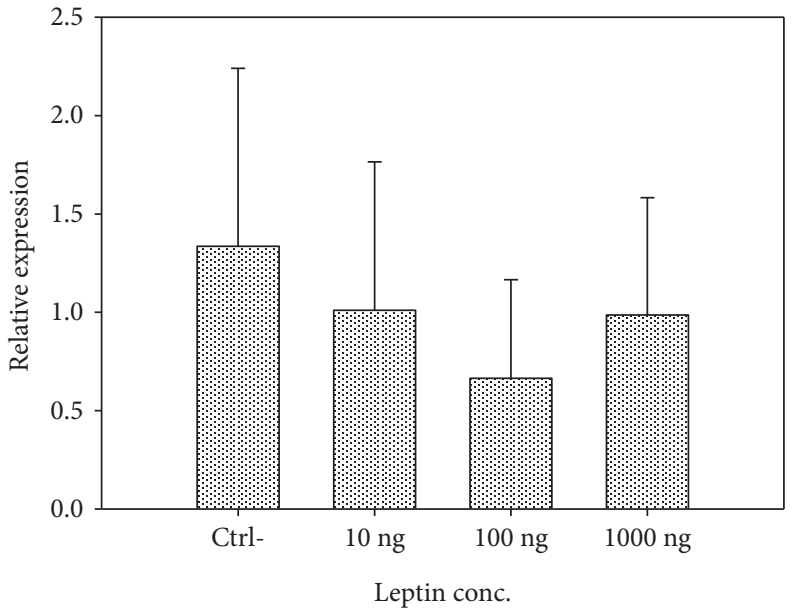

(d)

FIgURe 5: Units of relative expression of AdipoR1 and AdipoR2. The data is expressed as mean \pm SD. In MCF-7 breast cancer cells, there is a $2.92 \%$ decrease in the expression of AdipoR1 (a) in cells treated with leptin $(100 \mathrm{ng} / \mathrm{mL})$ with regard to the control and of $3.81 \%$ for the concentration of $1000 \mathrm{ng} / \mathrm{mL}$, except at $10 \mathrm{ng} / \mathrm{mL}$, where there was a $64.03 \%$ increase; the expression of AdipoR2 (b) increased by 13.74 times in cells treated with leptin $(10 \mathrm{ng} / \mathrm{mL})$ with regard to the control, 9.23 times for $100 \mathrm{ng} / \mathrm{mL}$, and 11.39 times for $1000 \mathrm{ng} / \mathrm{mL}$, finding significant differences compared to the control in all concentrations. With regard to the HCC1937 breast cancer cells, the expression of AdipoR1 (c) presented an $86.28 \%$ decrease in cells treated with leptin $(10 \mathrm{ng} / \mathrm{mL})$ with regard to the control, $13.72 \%$ (100 ng/mL), and 77.14\% (1000 ng/mL), finding significant differences for $10 \mathrm{~g} / \mathrm{mL}$ and $1000 \mathrm{ng} / \mathrm{mL}$; the expression of AdipoR2 (c) exhibited a $24.4 \%$ decrease in cells treated with leptin $(10 \mathrm{ng} / \mathrm{mL})$, with regard to the control, $50.3 \%(100 \mathrm{ng} / \mathrm{mL})$, and $26.2 \%(1000 \mathrm{ng} / \mathrm{mL})$; however, no significant differences were found in any of the concentrations relative to control. * Significant differences compared to the control ( $U$ of Mann-Whitney, $p \leq 0.05$ ).

tissue in a condition of normal weight $(10 \mathrm{ng} / \mathrm{mL})$, excess weight-obesity $(100 \mathrm{ng} / \mathrm{mL})$, and a very high concentration of leptin $(1000 \mathrm{ng} / \mathrm{mL})$.

In group 1 of the MCF-7 breast cancer cells, it was observed that the effect of leptin over cell proliferation was antiproliferative, decreasing up to $64.71 \%$. It was also observed that this antiproliferative effect is due to the sensibility of the cells while being recultured (period of cellular adaptation) and to the immediate administration of an exogenous agent, since despite that there was a decrease in the cell population during the first stimulation with leptin $(24 \mathrm{~h})$, in the posterior stimulations ( 48 and $72 \mathrm{~h}$ ), there was a gradual increase in cell population with regard to the population obtained at $24 \mathrm{~h}$ of stimulation. An increase of $0.65 \%$ and
$9.50 \%$ for the concentration of $10 \mathrm{ng} / \mathrm{mL}$ at $48 \mathrm{~h}$ and $72 \mathrm{~h}$, an increase of $12.04 \%$ and $69.23 \%$ for $100 \mathrm{ng} / \mathrm{mL}$ at $48 \mathrm{~h}$ and $72 \mathrm{~h}$, and an increase of $12.04 \%$ and $139.74 \%$ for $1000 \mathrm{ng} / \mathrm{mL}$ at $48 \mathrm{~h}$ and $72 \mathrm{~h}$, respectively, were observed, which indicate that the greater the concentration of leptin, the greater the increase in cell population. Likewise, the cells to which 4 stimuli of leptin were administered ( $96 \mathrm{~h}$ ) showed a major decrease in cell population with regard to the control ( $10 \mathrm{ng} / \mathrm{mL}: 45.09 \% ; 100 \mathrm{ng} / \mathrm{mL}: 56.86 \%$; and $1000 \mathrm{ng} / \mathrm{mL}$ : $64.71 \%)$, possibly due to a saturation of the cell receptors by leptin.

In the MCF-7 breast cancer cells of group 2, the effect of leptin over cell proliferation was positive, increasing up to $28.57 \%$, except for the concentration of $100 \mathrm{ng} / \mathrm{mL}$, in which 
TABle 1: Relative expression of AdipoR1 and AdipoR2.

\begin{tabular}{lccc}
\hline Cell line & $\begin{array}{c}\text { Leptin } \\
\text { concentration } \\
(\mathrm{ng} / \mathrm{mL})\end{array}$ & $\begin{array}{c}2^{-\Delta \Delta \mathrm{CT}} \\
\text { AdipoR1 }\end{array}$ & $2^{-\Delta \Delta \mathrm{CT}}$ AdipoR2 \\
\hline MCF-7 & 10 & $2.754 \pm 0.701$ & $33.31 \pm 16.006^{* *}$ \\
& 100 & $1.63 \pm 1.74$ & $22.354 \pm 14.006^{* *}$ \\
& 1000 & $1.615 \pm 1.209$ & $27.607 \pm 21.102^{* *}$ \\
HCC1937 & 10 & $0.162 \pm 0.129^{* *}$ & $1.01 \pm 0.755$ \\
& 100 & $1.019 \pm 1.423$ & $0.664 \pm 0.502$ \\
& 1000 & $0.27 \pm 0.27^{*}$ & $0.986 \pm 0.597$ \\
\hline
\end{tabular}

$2^{-\Delta \Delta \mathrm{CT}}$ Relative expression using BACT as a constitutive gene. The data is expressed as mean $\pm \mathrm{SD}, n=6$. In statistical Mann-Whitney $U$ test, significance with regard to the control ${ }^{*} p \leq 0.05,{ }^{* *} p \leq 0.01$.

at $72 \mathrm{~h}$ of stimulation, the cell population decreased up to 26.68\% (10 ng/mL, $48 \mathrm{~h})$ and was maintained until $72 \mathrm{~h}$ at the concentration of $1000 \mathrm{ng} / \mathrm{mL}$, where there was a $3.45 \%$ increase with regard to the control. This effect could be due to the elimination of the cellular adaptation period, since the cells were left to grow for another $24 \mathrm{~h}$ before the addition of exogenous agent (leptin) to the medium, allowing the cells to grow stronger, so as to not be damaged by the protein.

In the HCC1937 breast cancer cells of group 1, the effect of leptin over cell proliferation was negative at all concentrations evaluated (57.14\%). As in the case of the MCF-7 breast cancer cells, it was observed that this antiproliferative effect is due to the sensibility of the cells while being recultured and the immediate administration of leptin; since despite a decrease in the cell population during the first stimulation with leptin $(24 \mathrm{~h})$, in the second, there was a small increase in the population with regard to the cells obtained at $24 \mathrm{~h}$ of stimulation: for the concentration of $10 \mathrm{ng} / \mathrm{mL}$, an increase of $60 \%$; for $100 \mathrm{ng} / \mathrm{mL}$, an increase of $40 \%$; and for $1000 \mathrm{ng} /$ $\mathrm{mL}$, an increase of $28.33 \%$. However, this effect was not maintained with posterior stimulations.

The aforementioned results demonstrate that the period of cellular adaptation interferes with the effect of leptin over MCF-7 and HCC1937 proliferation, in which the period of cellular adaptation posterior to culture is between 2 and 3 days. In these cell lines, there was a positive effect over cell proliferation at all concentrations administered, when the first stimuli was administered $48 \mathrm{~h}$ after cell culture. Based on these results, it was decided that a cell stimulation be done with leptin 48 hours after cell culture.

An important find from the detection of leptin, adiponectin, AdipoR1, and AdipoR2 mRNA in breast cancer cells through endpoint PCR was that in HCC1937, a triple-negative cell line with a mutation in BRCA1 [44], these proteins and receptors are also found to be expressed, information that had not been reported in the literature. The aforementioned means that indistinctly of the molecular classification of breast cancer to which the cell lines belong, they can express leptin, adiponectin, and its receptors, allowing for the possibility of a future treatment for triple-positive breast cancer patients, patients with negative breast cancer, and patients with triple-negative breast cancer with mutations in BRCA1.

As for the expression assay, in MCF-7 breast cancer cells, the expression of mRNA of AdipoR2 (2.423 \pm 2.35$)$ was greater than the expression of AdipoR1 (1.679 \pm 1.76$)$. For the stimulations with leptin, it was found that the expression of AdipoR1 mRNA decreased with regard to the control in the cells that received $100 \mathrm{ng} / \mathrm{mL}$ and $1000 \mathrm{ng} / \mathrm{mL}$ of up to $3.81 \%$, while the cells that received a stimulus of $10 \mathrm{ng} / \mathrm{mL}$ showed a $64.03 \%$ increase in expression. Surprisingly, the expression of AdipoR2 mRNA was dramatically increased at all concentrations of leptin: $10 \mathrm{ng} / \mathrm{mL}$ (13.75 times), $100 \mathrm{ng} / \mathrm{mL}$ (9.23 times), and $1000 \mathrm{ng} / \mathrm{mL}$ (11.39 times). Once again, the concentration at which there was a greater increase in the expression of the adiponectin receptor was at the "normal weight" concentration $(10 \mathrm{ng} / \mathrm{mL})$, which could indicate that in a condition of normal weight $(10 \mathrm{ng} / \mathrm{mL})$, at a high level of AdipoR1 and AdipoR2, the adiponectin could successfully carry out its antiproliferative activity of cancer cells and, in this manner, generate a form of protection for the patient.

The reduction in the expression of AdipoR1 in MCF-7 breast cancer cells corresponds with that proposed in the hypothesis of the present work, since in cells that received higher concentrations of leptin $(100 \mathrm{ng} / \mathrm{mL}=$ excess weightobesity; $1000 \mathrm{ng} / \mathrm{mL}$ ), a decrease in the expression of mRNA of the gen was observed with regard to the control, while the cells that received stimulation with a concentration corresponding to normal weight showed an increase in the expression of both receptors. On the other hand, the increase in the expression of AdipoR2 mRNA and the decrease in the cell population at all concentrations at $96 \mathrm{~h}$ of stimulation could indicate that the effective receptor for the in vivo signaling of adiponectin in the breast cancer tissue is AdipoR2; this corresponds to that found in 2009 by Jardé et al. [27].

Despite this evidence, the notion of the effective receptor for adiponectin is uncertain, since it has been found that when siRNA was used against AdipoR1, the antiproliferative activity of adiponectin in T47D cells was annulated [30]. Likewise, studies have established a relationship between the presence of AdipoR1 and a better diagnosis in gastric and colon cancers $[50,51]$.

With regard to the expression of AdipoR1 and AdipoR2 mRNA in HCC1937 breast cancer cells, as in the case of MCF-7 cells, the expression of AdipoR2 mRNA (1.336 \pm 0.905) was greater than the expression of AdipoR1 (1.181 \pm 0.67). However, contrary to that found in MCF-7, there was a decrease in the expression of AdipoR1 mRNA of up to $86.26 \%(10 \mathrm{ng} / \mathrm{mL})$, when stimulated with leptin, and up to $50.3 \%(100 \mathrm{ng} / \mathrm{mL})$ for the expression of AdipoR2 mRNA. These results correspond to that found in cell viability curves (Figure 4), where it can be seen, in a much more marked manner, that there is a positive stimulation over cell proliferation at all concentrations of leptin employed due to the lack of antiproliferative activity offered by adiponectin through its receptors, generated from the decrease in the mRNA expression of these.

For HCC1937 cells, a part of the hypothesis proposed was corroborated for AdipoR1 and AdipoR2, due to the fact that 
there was a decrease in the expression of mRNA in both cell receptors in the cells that received stimulation from leptin every $24 \mathrm{~h}$. Contrary to what is expected, a greater decrease of expression was found in concentrations corresponding to normal weight $(10 \mathrm{ng} / \mathrm{mL})$ and excess weight-obesity $(100 \mathrm{ng} / \mathrm{mL})$, which could indicate that in a condition of excess weight and obesity, there is a blockage in the expression of these receptors, which leads to adiponectin not being able to carry out its protective (antiproliferative) action during the development of breast cancer.

In our study, one of the limitations found was that the effect of leptin on cell proliferation and expression of AdipoR1 and AdipoR2 was modest, due to the range of leptin concentrations used to perform the cellular stimulus was very wide, which did not allow to identify exactly the effect that this protein has on the gene expression of these receptors in a state of obesity. On the other hand, it is impossible to extrapolate the results obtained from leptin stimulation in the cell lines with the results of expression that could be obtained directly from obese patients with breast cancer due to the complexity of the metabolic environment of the tumor in vivo.

\section{Conclusion}

In this study, the effect of leptin over cell proliferation and genic expression of AdipoR1 and AdipoR2 in MCF-7 and HCC1937 cells was modest. Indistinctly of the molecular classification of breast cancer of the cell lines used, they all express leptin, adiponectin, AdipoR1, and AdipoR2. It was determined that the period of cell adaptation generates an interference with the effect of leptin over the proliferation of MCF-7 and HCC1937 cells. During the development of breast cancer, the capacity of proliferation $(23.68 \%$ for MCF-7 and 17.24\% for HCC1937), explained by the deregulation of leptin in obesity, could be very relevant at the moment of prescribing a treatment to the patient. The concentration of leptin that generated an increase in the expression of both receptors of adiponectin was that corresponding to normal weight $(10 \mathrm{ng} / \mathrm{mL})$, indicating that in said condition, adiponectin can successfully carry out its antiproliferative activity over cancer cells and, in this manner, generate a form of protection for the patient.

The reduction in the expression of AdipoR1 mRNA and the increase in the expression of AdipoR2 mRNA could indicate that the effective receptor for the in vivo signaling of adiponectin in breast cancer tissue is AdipoR1.

\section{Conflicts of Interest}

The authors declare no conflict of interest.

\section{Acknowledgments}

This work was supported by the Autonomous University of the State of Mexico and the IMIEM Specialized HematoOncological Laboratory.

\section{References}

[1] T. Jardé, F. Caldefie-Chézet, M. Damez et al., "Leptin and leptin receptor involvement in cancer development: a study on human primary breast carcinoma," Oncology Reports, vol. 19, pp. 905-911, 2008.

[2] L. M. Morimoto, E. White, Z. Chen et al., "Obesity, body size, and risk of postmenopausal breast cancer: the women's health initiative (United States)," Cancer Causes and Control, vol. 13, pp. 741-751, 2002.

[3] M. J. Khandekar, P. Cohen, and B. M. Spiegelman, "Molecular mechanisms of cancer development in obesity," Nature Reviews, vol. 11, pp. 886-895, 2011.

[4] T. Jardé, S. Perrier, M. P. Vasson, and F. Caldefie-Chézet, "Molecular mechanisms of leptin and adiponectin in breast cancer," European Journal of Cancer, vol. 47, pp. 33-43, 2011.

[5] C. E. Ruhl and J. E. Everhart, "Leptin concentrations in the United States: relations with demographic and anthropometric measures," The American Journal of Clinical Nutrition, vol. 74, pp. 295-301, 2001.

[6] H. S. Moon, M. Dalamaga, S. Y. Kim et al., "Leptin's role in lipodystrophic and nonlipodystrophic insulin resistant and diabetic individuals," Endocrine Reviews, vol. 34, pp. 377412, 2013.

[7] M. Dalamaga, S. H. Chou, K. Shields, P. Papageorgiou, S. A. Polyzos, and C. S. Mantzoros, "Leptin at the intersection of neuroendocrinology and metabolism: current evidence and therapeutic perspectives," Cell Metabolism, vol. 18, pp. 2942, 2013.

[8] D. Housa, J. Housová, Z. Vernerová, and M. Haluzík, “Adipocytokines and cancer," Physiological Research, vol. 55, pp. 233244, 2006.

[9] L. Delort, T. Jardé, V. Dubois, M. P. Vasson, and F. CaldefieChézet, "New insights into anticarcinogenic properties of adiponectin: a potential therapeutic approach in breast cancer?," Vitamins and Hormones, vol. 90, pp. 397-417, 2012.

[10] Y. Matsuzawa, T. Funahashi, S. Kihara, and I. Shimomura, "Adiponectin and metabolic syndrome," Arteriosclerosis, Thrombosis, and Vascular Biology, vol. 24, pp. 29-33, 2004.

[11] C. M. López Fontana, M. E. Maselli Artola, N. Di Milta Mónaco et al., "Influencia de la leptina y la adiponectina sobre el cáncer de próstata," Archivos Españoles de Urología, vol. 62, no. 2, pp. 103-108, 2009.

[12] J. Thundyil, D. Pavlovski, C. G. Sobey, and T. V. Arumugam, "Adiponectin receptor signalling in the brain," British Journal of Pharmacology, vol. 165, pp. 313-327, 2011.

[13] M.-H. Lee, R. L. Klein, H. M. El-Shewy, D. K. Luttrell, and L. M. Luttrell, "The adiponectin receptors AdipoR1 and AdipoR2 activate ERK1/2 through a Src/Ras-dependent pathway and stimulate cell growth," Biochemistry, vol. 47, no. 44, pp. 11682-11692, 2008.

[14] M. Chandran, S. A. Phillips, T. Ciaraldi, and R. R. Henry, "Adiponectin: more than just another fat cell hormone?," Diabetes Care, vol. 26, pp. 2442-2450, 2003.

[15] A. Fujimoto, S. Akifusa, N. Kamio, T. Hirofuji, K. Nonaka, and Y. Yamashita, "Involvement of mTOR in globular adiponectin-induced generation of reactive oxygen species," Free Radical Research, vol. 44, pp. 128-134, 2010.

[16] Y. Arita, S. Kihara, N. Ouchi et al., "Paradoxical decrease of an adipose-specific protein, adiponectin, in obesity," Biochemical 
and Biophysical Research Communications, vol. 257, no. 1, pp. 79-83, 1999.

[17] R. Fusco, M. Galgani, C. Procaccini et al., "Cellular and molecular crosstalk between leptin receptor and estrogen receptor- $\{$ alpha\} in breast cancer: molecular basis for a novel therapeutic setting," Endocrine-Related Cancer, vol. 17, no. 2, pp. 373-382, 2010.

[18] K. A. Frankenberry, H. Skinner, P. Somasundar, D. W. McFadden, and L. C. Vona-Davis, "Leptin receptor expression and cell signaling in breast cancer," International Journal of Oncology, vol. 28, no. 4, pp. 985-993, 2006.

[19] K. J. Nkhata, A. Ray, T. F. Schuster, M. E. Grossmann, and M. P. Cleary, "Effects of adiponectin and leptin co-treatment on human breast cancer cell growth," Oncology Reports, vol. 21, no. 6, pp. 1611-1619, 2009.

[20] C. Garofalo, D. Sisci, and E. Surmacz, "Leptin interferes with the effects of the antiestrogen ICI 182, 780 in MCF-7 breast cancer cells," Clinical Cancer Research, vol. 10, no. 19, pp. 6466-6475, 2004.

[21] N. Yin, D. Wang, H. Zhang et al., "Molecular mechanisms involved in the growth stimulation of breast cancer cells by leptin," Cancer Research, vol. 64, pp. 5870-5875, 2004.

[22] J. G. Santillan Benitez, A. Ordoñez, Z. H. Mendieta, and L. M. Gómez Oliván, "La leptina en la carcinogénesis mamaria. Vías de señalización," Química Viva, vol. 2, no. 11, pp. 91-111, 2012.

[23] M. Okumura, M. Yamamoto, H. Sakuma et al., "Leptin and high glucose stimulate cell proliferation in MCF-7 human breast cancer cells: reciprocal involvement of PKCalpha and PPAR expression," Biochimica et Biophysica Acta (BBA) - Molecular Cell Research, vol. 1592, no. 2, pp. 107116, 2002.

[24] R. R. Gonzalez, S. Cherfils, M. Escobar et al., "Leptin signaling promotes the growth of mammary tumors and increases the expression of vascular endothelial growth factor (VEGF) and its receptor type two (VEGF-R2)," The Journal of Biological Chemistry, vol. 281, no. 36, pp. 26320-26328, 2006.

[25] N. A. Binai, A. Damert, G. Carra et al., "Expression of estrogen receptor alpha increases leptin-induced STAT3 activity in breast cancer cells," International Journal of Cancer, vol. 127, no. 1, pp. 55-66, 2010.

[26] C. Chen, Y. C. Chang, C. L. Liu, K. J. Chang, and I. C. Guo, "Leptin-induced growth of human ZR-75-1 breast cancer cells is associated with up-regulation of cyclin D1 and c-Myc and downregulation of tumor suppressor p53 and p21WAF1/ CIP1," Breast Cancer Research and Treatment, vol. 98, no. 2, pp. 121-132, 2006.

[27] T. Jarde, F. Caldefie-Chezet, N. Goncalves-Mendes et al., "Involvement of adiponectin and leptin in breast cancer: clinical and in vitro studies," Endocrine-Related Cancer, vol. 16, no. 4, pp. 1197-1210, 2009.

[28] M. N. Dieudonne, M. Bussiere, E. Dos Santos, M. C. Leneveu, Y. Giudicelli, and R. Pecquery, "Adiponectin mediates antiproliferative and apoptotic responses in human MCF7 breast cancer cells," Biochemical and Biophysical Research Communications, vol. 345, no. 1, pp. 271-279, 2006.

[29] L. Taliaferro-Smith, A. Nagalingam, D. Zhong, W. Zhou, N. K. Saxena, and D. Sharma, "LKB1 is required for adiponectinmediated modulation of AMPK-S6K axis and inhibition of migration and invasion of breast cancer cells," Oncogene, vol. 28, no. 29, pp. 2621-2633, 2009.
[30] S. Nakayama, Y. Miyoshi, H. Ishihara, and S. Noguchi, "Growth inhibitory effect of adiponectin via adiponectin receptor 1 on human breast cancer cells through inhibition of S-phase entry without inducing apoptosis," Breast Cancer Research and Treatment, vol. 112, no. 3, pp. 405-410, 2007.

[31] Y. Wang, J. B. Lam, K. S. Lam et al., “Adiponectin modulates the glycogen synthase kinase-3beta/beta-catenin signaling pathway and attenuates mammary tumorigenesis of MDAMB-231 cells in nude mice," Cancer Research, vol. 66, no. 23, pp. 11462-11470, 2006.

[32] J. H. Kang, Y. Y. Lee, B. Y. Yu et al., "Adiponectin induces growth arrest and apoptosis of MDA-MB-231 breast cancer cell," Archives of Pharmacal Research, vol. 28, no. 11, pp. 1263-1269, 2005.

[33] A. Korner, K. Pazaitou-Panayiotou, T. Kelesidis et al., "Total and high-molecular-weight adiponectin in breast cancer: in vitro and in vivo studies," The Journal of Clinical Endocrinology \& Metabolism, vol. 92, no. 3, pp. 1041-1048, 2007.

[34] M. E. Grossmann, K. J. Nkhata, K. MizunoN, A. Ray, and M. P. Cleary, "Effects of adiponectin on breast cancer cell growth and signaling," British Journal of Cancer, vol. 98, pp. 370-379, 2008.

[35] E. Dos Santos, D. Benaitreau, M. N. Dieudonne et al., "Adiponectin mediates an antiproliferative response in human MDA-MB 231 breast cancer cells," Oncology Reports, vol. 20, no. 4, pp. 971-977, 2008.

[36] O. Treeck, C. Lattrich, I. Juhasz-Boess, S. Buchholz, G. Pfeiler, and O. Ortmann, "Adiponectin differentially affects gene expression in human mammary epithelial and breast cancer cells," British Journal of Cancer, vol. 99, no. 8, pp. 12461250, 2008.

[37] D. Soma, J. Kitayama, H. Yamashita, H. Miyato, M. Ishikawa, and H. Nagawa, "Leptin augments proliferation of breast cancer cells via transactivation of HER2," The Journal of Surgical Research, vol. 149, no. 1, pp. 9-14, 2008.

[38] P. Somasundar, A. K. Yu, L. Vona-Davis, and D. W. McFadden, "Differential effects of leptin on cancer in vitro," The Journal of Surgical Research, vol. 113, no. 1, pp. 50-55, 2003.

[39] F. J. García Vázquez and J. E. Farfán Morales, "Manual Técnicas de Herramientas en Patología," Inmunohistoquímica, vol. 1, 2014.

[40] V. Dubois, L. Delort, H. Billard, M. P. Vasson, and F. Caldefie-Chezet, "Breast cancer and obesity: in vitro interferences between adipokines and proangiogenic features and/or antitumor therapies?", PLoS One, vol. 3, no. 8, article e58541, 2013.

[41] K. J. Livak and T. D. Schmittgen, "Analysis of relative gene expression data using real-time quantitative PCR and the 2(- Delta DeltaC(T)) method," Methods, vol. 25, pp. 402408, 2001.

[42] M. W. Pfaffl, "A new mathematical model for relative quantification in real-time RT-PCR," Nucleic Acids Research, vol. 29, pp. 2003-2007, 2001.

[43] T. D. Schmittgen and K. J. Livak, "Analyzing real-time PCR data by the comparative CT method," Nature Protocols, vol. 3, pp. 1100-1108, 2008.

[44] G. E. Tomlinson, T. T. Chen, V. A. Stasny et al., "Characterization of a breast cancer cell line derived from a germ-line BRCA1 mutation carrier," Cancer Research, vol. 58, pp. 3237-3242, 1998. 
[45] A. M. Lorincz and S. Sukumar, "Molecular links between obesity and breast cancer," Endocrine-Related Cancer, vol. 13, pp. 279-292, 2006.

[46] R. T. Chlebowski, E. Aiello, and A. McTiernan, "Weight loss in breast cancer patient management," Journal of Clinical Oncology, vol. 20, no. 4, pp. 1128-1143, 2002.

[47] A. F. Gazdar, V. Kurvari, A. Virmani et al., "Characterization of paired tumor and non-tumor cell lines established from patients with breast cancer," International Journal of Cancer, vol. 78, pp. 766-774, 1998.

[48] M. N. Dieudonne, F. Machinal-Quelin, V. Serazin-Leroy, M. C. Leneveu, R. Pecquery, and Y. Giudicelli, "Leptin mediates a proliferative response in human MCF7 breast cancer cells," Biochemical and Biophysical Research Communications, vol. 293, no. 1, pp. 622-628, 2002.

[49] S. Naviglio, D. Di Gesto, A. Sorrentino et al., "Leptin enhances growth inhibition by cAMP elevating agents through apoptosis of MDA-MB-231 breast cancer cells," Cancer Biology \& Therapy, vol. 8, no. 12, pp. 1183-1190, 2009.

[50] T. Tsukada, S. Fushida, S. Harada et al., "Adiponectin receptor-1 expression is associated with good prognosis in gastric cancer," Journal of Experimental \& Clinical Cancer Research, vol. 30, p. 107, 2011.

[51] A. Y. Kim, Y. S. Lee, K. H. Kim et al., "Adiponectin represses colon cancer cell proliferation via AdipoR1- and -R2-mediated AMPK activation," Molecular Endocrinology, vol. 24, no. 7, pp. 1441-1452, 2010. 


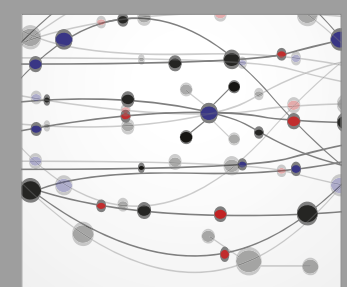

The Scientific World Journal
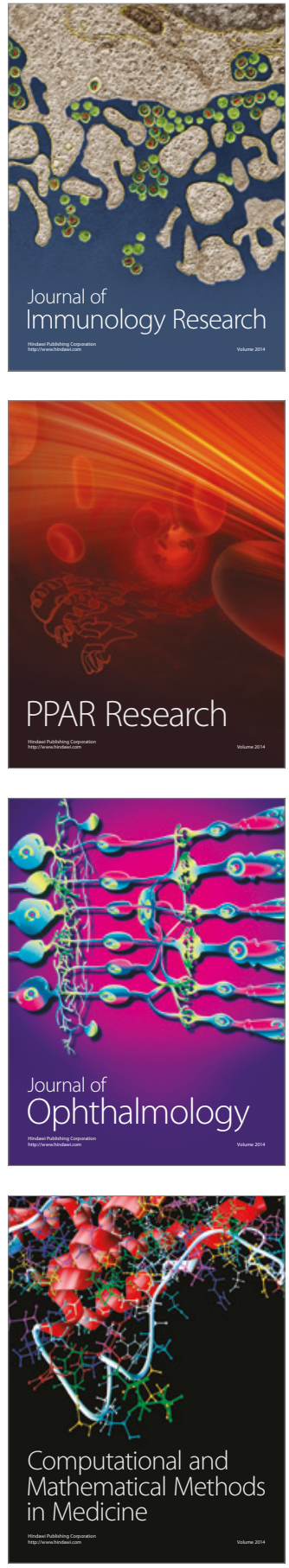

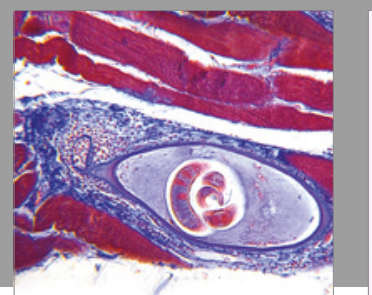

Gastroenterology Research and Practice
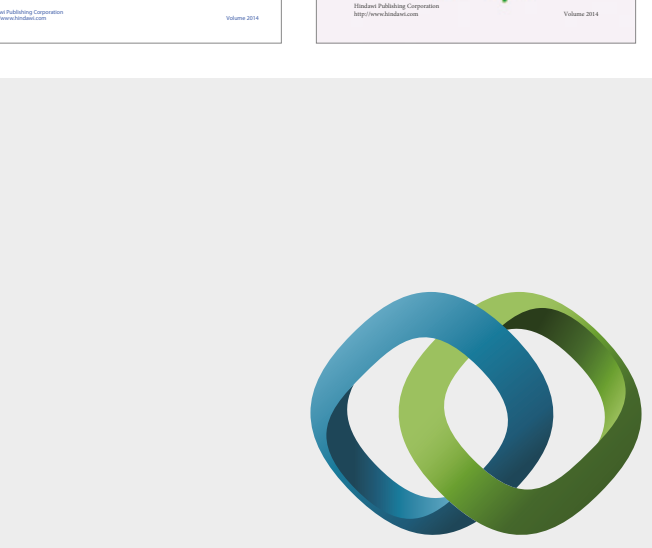

\section{Hindawi}

Submit your manuscripts at

https://www.hindawi.com
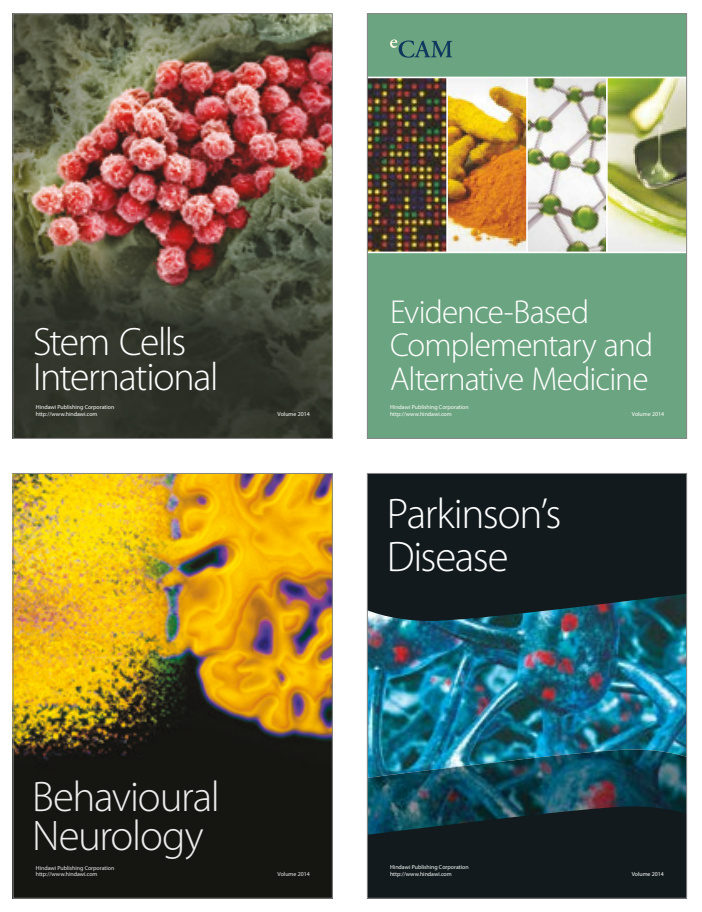
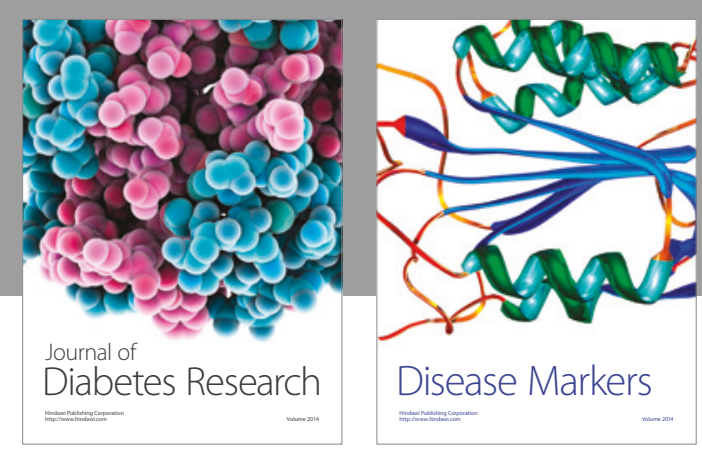

Disease Markers
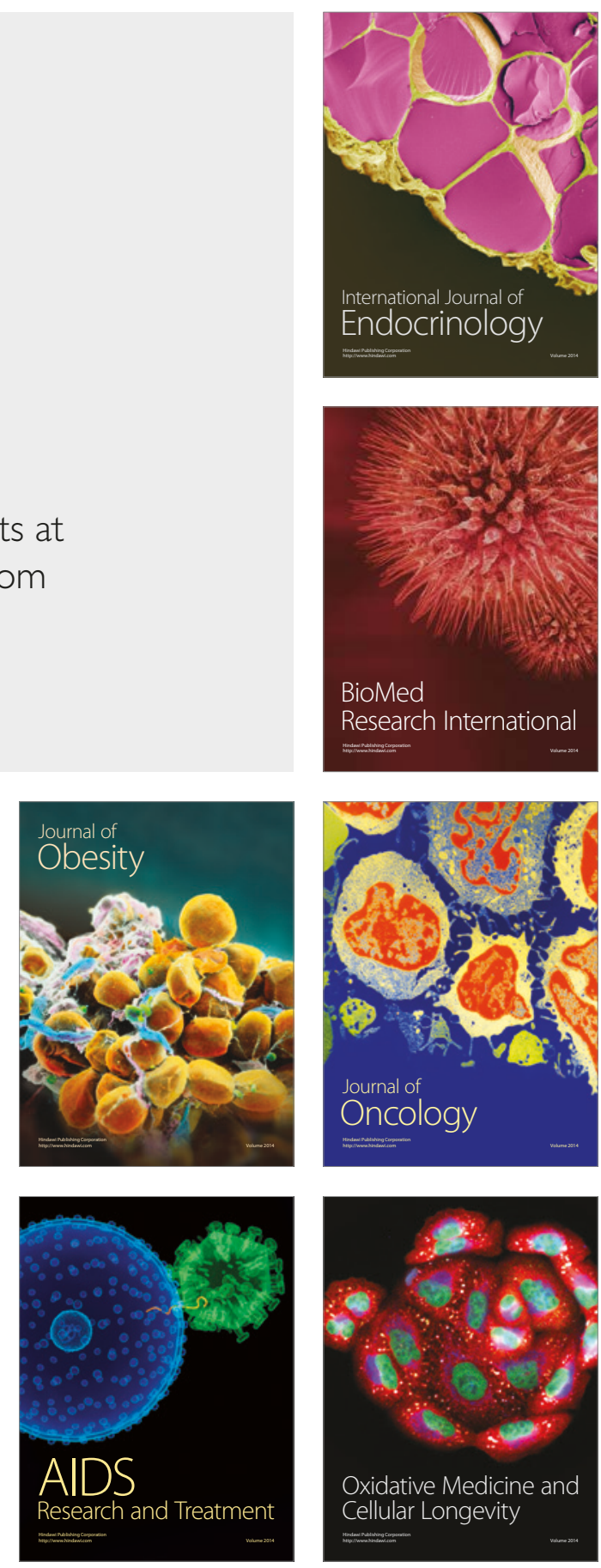